\title{
Post-Covid-19 Energy Transition Strategies: Even Reaching 100\% Renewable in Ecuador by 2055 is not Enough to Face Climate Change Issue
}

\author{
N. Norouzi, M. Fani* \\ ${ }^{1}$ Department of Energy Engineering and Physics, Amirkabir University of Technology (Tehran Polytechnic), 424 Hafez Avenue, PO. Box 15875-
} 4413, Tehran, Iran

\section{$P A P E R$ IN FO}

\section{Paper history:}

Received 24 February 2021

Accepted in revised form 01 September 2021

\section{Keywords:}

Covid-19

Energy transition

Power industry

Renewable energy

\section{A $B$ S $S$ T R A $A$ C T}

The pandemic scenario caused by Covid-19 generated negative impacts. Covid-19 has made it clear that our daily lives depend to a high degree on access to energy. Therefore, now more than ever, it is necessary to promote new activities such as local food production, but also local energy capture. This article is an attempt to expose and quantify the benefits of a renewable energy transition in Ecuador post Covid-19 and post-oil. The generation, consumption, and reserves of oil in Ecuador were characterized, and the concept of energy transition was applied to evaluate the possibilities of integration of renewables, the progressive exit of thermal power plants, and future energy strategies. The year 2015 was taken as a basis and it was determined that energy use was 154.0 TWh / year, which corresponds to an end-user of approximately $147 \mathrm{TWh} /$ year. The objective was to reduce this end-use demand to $80.0 \mathrm{TWh} /$ year by 2055 through the integration of renewables and energy efficiency, for which 5 transition phases were planned until a $100 \%$ renewable system was obtained. It is concluded that the energy transition in Ecuador is technically possible and economically viable, without giving up the energy well-being that we currently enjoy. However, results show that even $100 \%$ renewable is not enough to face climate change.

doi: 10.5829/ijee.2022.13.01.01

\section{INTRODUCTION}

Energy systems are an essential part of the functioning of cities, requiring a reliable and abundant supply of electricity, as well as other services such as water, fuel for transport, or food [1, 2]. In short, our daily life depends on access to energy. For a moment, imagine what we would do one day without hot water, without electricity, without gasoline, and in lockdown due to Covid-19. Given this very high dependency, it is paradoxical that we are not concerned with operating with an obsolete energy model [3-5].

Covid-19 by affecting the world economy and reducing the price of oil makes clear the need to change the energy model, overcome the era of dirty fossil fuels, and make the transition towards the era of clean energy flows [5]. A world based on renewable energy, clean of pollution, cheaper, is technically possible and economically viable. Now is the time for politics [6].
Without giving up one iota of the energy well-being that we currently enjoy, meeting the needs and preparing the system for the future [7].

The double crisis of fossil energy resources, availability due to depletion, and pollution forces us to advance in the renewable energy transition [8]. The detailed analysis of electrical uses, their links with the resources of the territory, the economy, and the environment offers very valuable information to project the energy transition [9].

In the last 5 decades, Ecuador has based its growth on fossil fuels, both in its energy uses for transport and mobility, industry, electricity generation, air conditioning in buildings, automotive agricultural machinery, etc. in its by-products (plastics, synthetic rubber, fibers, resins, packaging, bottles, clothes, carpets, diapers, cables, pipes, medicines, insecticides, aerosols, lighters, paints, etc.), which are part of our lives [10-15]. This has resulted in a

*Corresponding Author Email: : mfani@aut.ac.ir (M. Fani) 
strong dependence on fossil fuels that has put the sovereignty and economic stability of the country at risk. This dependence necessarily has to decrease because the generation of electricity with fossil fuels is costly and polluting [16]. In addition, the price of crude oil has shown great volatility in recent years, making it impossible to make medium-term projections [11]. Covid-19 has only exaggerated this trend of price instability due to falling demand for oil [17]. In addition, an unprecedented economic crisis is anticipated, which reveals the volatility of the current energy model based on fossil fuels and global energy markets, with great environmental and social impacts both in producing and consuming areas [18]. Therefore, the need to accelerate the transition to renewable energy sources in Ecuador is unavoidable [7]. In this scenario of Covid-19 and energy transition, the importance of emphasizing the context of each country is highlighted, since economic, social, political, and geographical particularities are factors that will influence the implementation of the energy transition [19].

In the case of Ecuador, it is essential to reduce external dependence on fossils, therefore, the energy transition is one of the vectors that must be implemented to reduce the bill that is paid for importing what is called primary energy in the form of fossil fuels (derived from oil and gas).

\section{METHOD}

The method is based on the application of the temporary energy transition model. The most recent analyzes of the transformation of the energy system offer an overview and outline some key characteristics of the energy transition [20-23]: they analyze the energy needs of a territory [9], they determine the order of implementation of renewable energies [10] and some are betting on hydrogen as an energy vector to store renewable energy to solve the problem of synchronism between electricity generation and consumption due to the intermittences of renewables [24]. The concept of temporary implementation of energy transition shown in Figure 1 is based on models that describe the demand and supply of energy using aggregate figures that are very useful to explain the national and regional context of territory in transition [25]. The data have been taken from official sources, the electricity generation of the National Electricity Operator (CENACE), the consumptions of the Ministry of Electricity and Renewable Energy (MEER), the natural resources of the Latin American Energy Organization (OLADE), and reserves of oil from the Organization of Petroleum Exporting Countries (OPEC) [26].

However, considering mentioned facts is very important in the implementation of every energy transition plan, but a structural shift is occurring across industries stemming from social, environmental, and governmental pressures towards a low-carbon and sustainable future. These changes are growing in number, due to the sustainable development goal and global interest in climate change mitigation programs [27].

This paper proposes Figure 1 as an energy transition insights schema to help to structure every program implemented in this section and across the complete energy and natural resources, chemicals, and agribusiness industries to provide the most comprehensive intelligence available on the changing energy landscape.

\section{RESULTS AND DISCUSSION}

\section{Energy system details}

A quantitative analysis of the energy production of Ecuador was carried out. In Figure 2, it is observed that in $201881 \%$ of the production corresponds to oil, $4.5 \%$ to natural gas, $4 \%$ to biofuels and waste, and $10.5 \%$ to hydropower [28].

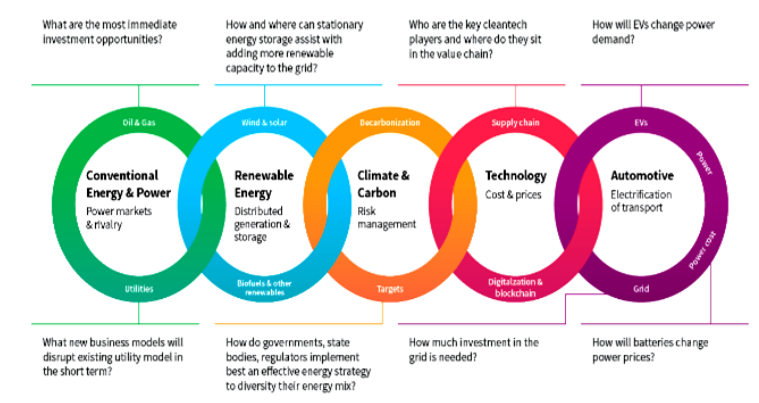

Figure 1. Scheme of the key drivers of the energy transition and questions which must be answered in any planning and strategy for energy transition phenomena. Source: Author-made

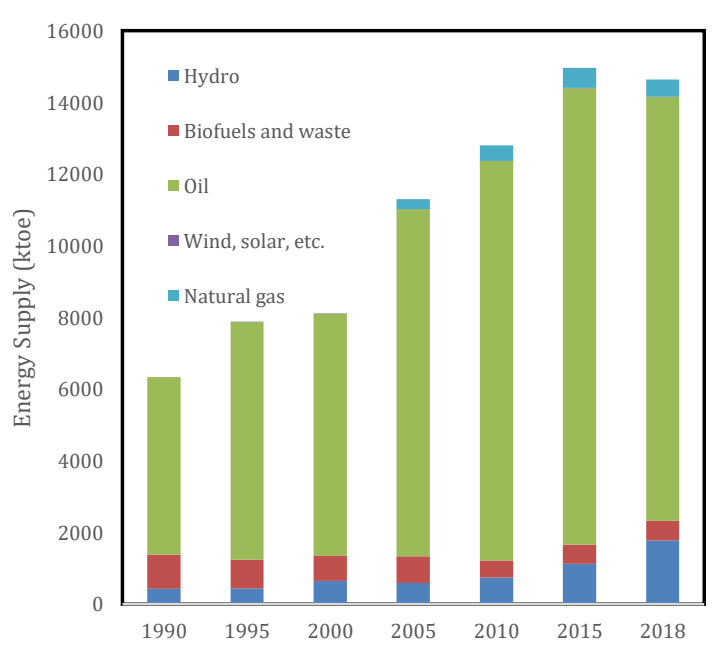

Figure 2. Energy supply 1990-2018 Source: Author made 
A quantitative analysis of the electric power generation of Ecuador was carried out. In Figure 3, it is observed that in $201783.88 \%$ of the production corresponds to hydroelectric generation, $14.4 \%$ to thermoelectric generation, $1.64 \%$ to non-conventional generation, and $0.08 \%$ to the imports from Colombia, and energy from Peru is stopped being imported [29-32].

A quantitative analysis of energy consumption in Ecuador by sector was carried out from 1990 to 2019. In Figure 4 the evolution of energy consumption by sector is shown. From 1994 to 2000 Ecuador suffered a series of events that affected its stability. In 1998 the phenomenon of El Niño. Between 1998 and 1999, oil prices fell. In 1999 and 2000 the national financial system was affected by the bank holiday [33]. As a result, in 1999 per capita income fell by $9 \%$, and it is estimated that at this time that at least 700,000 Ecuadorians emigrated to European countries and the United States of America. Starting in 2000 , a slight recovery begins that tends to stagnate in 2003 due to political instability. The energy consumption portfolio in the country has consisted of $49.1 \%$ in transportation, $15 \%$ in the industry, $14 \%$ in the residential sector, $8.1 \%$ in the commercial sector, $2.9 \%$ in agriculture, $1.9 \%$ in non-energy use, and $9 \%$ in the other non-specific parts like military, etc. [34].

In the last four decades there has been an accelerated increase in the consumption of fossil fuels, especially for transport with internal combustion engines, so that, in parallel, there is also an accelerated increase in greenhouse effect emissions. This added to the depletion of oil reserves makes the need to plan an energy transition urgent and accelerated [35].

The Latin American Energy Organization (OLADE) has determined that the usable water potential of Ecuador is approximately $21,900 \mathrm{MW}$. Only $15 \%$ of this total available has been exploited. According to the Solar Atlas of Ecuador for electricity generation purposes, the solar resource that Ecuador's surface receives is $4,245 \mathrm{Wh} / \mathrm{m}^{2} . \mathrm{d}$

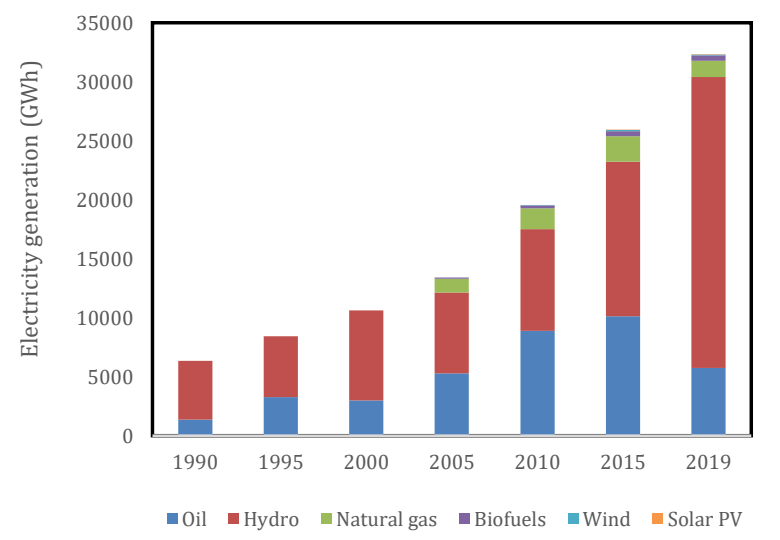

Figure 3. Electricity generation 1990-2019. Source: Authormade of average annual insolation. Insolation levels above 4000 $\mathrm{Wh} / \mathrm{m}^{2} . \mathrm{d}$ are considered technically and economically feasible [36].

According to the Minister of Electricity and Renewable Energy of Ecuador, the minimum wind potential is 884.22 MW of capacity, in short-term projects. Technically usable sites with annual average wind speeds above $7 \mathrm{~m} / \mathrm{s}$, below 3000 meters above sea level, and with a distance of less than $10 \mathrm{~km}$ from the transmission networks and highways have a capacity of $155 \mathrm{MW}$ in continental Ecuador. On the other hand, according to the plan for the use of geothermal resources in Ecuador, there is a theoretical potential of $6500 \mathrm{MW}$ and in pre-feasibility studies $400 \mathrm{MW}$ [37].

If all this usable potential of solar, wind, hydraulic and geothermal energy is exploited, it would seem sufficient power to cover national demand, but this is not the case due to the dry season, where more than $40 \%$ of thermal power plants would have to be integrated into the national interconnected system SNI. However, it was considered reasonable to assign a target demand of $80.0 \mathrm{TWh} /$ year, which is the sum of the usable resources [30].

The concept of temporary implementation of the energy transition provides several post-fossil alternatives. The diagram in Figure 2 summarizes in general terms what planning for the orderly development of a new energy model could be. The year 2015 is taken as a base and evolves until a $100 \%$ renewable energy system is obtained in a 40-year period in which an ordered correlation can be established in 4 phases of 10 years [18, 31].

In the case of Ecuador, we have that primary energy use in 2015 was 154.0 TWh/year, which corresponds to an end-user of approximately $147 \mathrm{TWh} /$ year, having an end-use demand target of $80.0 \mathrm{TWh} / \mathrm{year}$ by 2055 [38].

\section{Energy transition}

Ecuador's Constitution of 2008 explicitly states that the

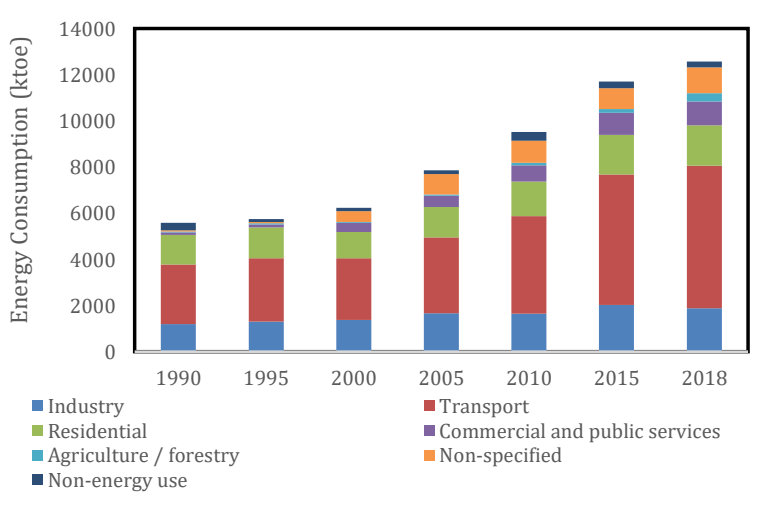

Figure 4. Evolution of energy consumption by sectors. Source: Author-made 
government will promote the use of clean and alternative energy sources [39]. This commitment sits alongside other pledges to promote energy efficiency, provide access to public services, preserve the environment and maintain food and water security, among others. In August 2015, the Ecuadorian government announced a 7 billion U. S. dollars (USD) program for the country's energy transformation. Government officials stated that by the end of 2015, 93 percent of the country's electricity will be sourced from hydropower. The country is also investing in other forms of renewable energy, such as wind power through the $16.5 \mathrm{MW}$ wind farm in Villonaco and solar energy projects in the Galapagos Islands [40].

The National Plan for Good Living 2013-2022 (PNBVSENPLADES 2013-2017) sets a target of reaching 60 percent of national capacity from renewable energy sources by 2017. Objective 11.1 of this National Plan lays special emphasis on hydropower and bioenergy. The Electrification Master Plan 2013-2055, approved by Resolution CONELEC 041/13 [41], puts forward plans for 25 hydropower projects totaling $4.2 \mathrm{GW}$ of new capacity by 2022 , as well as an additional $217 \mathrm{MW}$ of solar, wind, and other non-conventional renewables. Previously, the National Plan for Good Living 2009-2013 had set out a target of six percent of installed capacity being sourced from renewable energy which was ultimately successful in decreasing the share of unrenewable energy in Ecuador's portfolio (other than large hydro) by 2013 (see Figures. 3 and 5) [42].

Figure 6 shows that Ecuador has been a successful case in greening the energy sector and move toward the $100 \%$ transition. The least impact of Energy intensity and carbon intensity of the energy section in the rising Carbon emission index shows this fact [43]. However, this figure shows the fact that the decarbonization of the energy section or transition to $100 \%$ renewable is not enough to control the growing climate change concerns. Therefore,

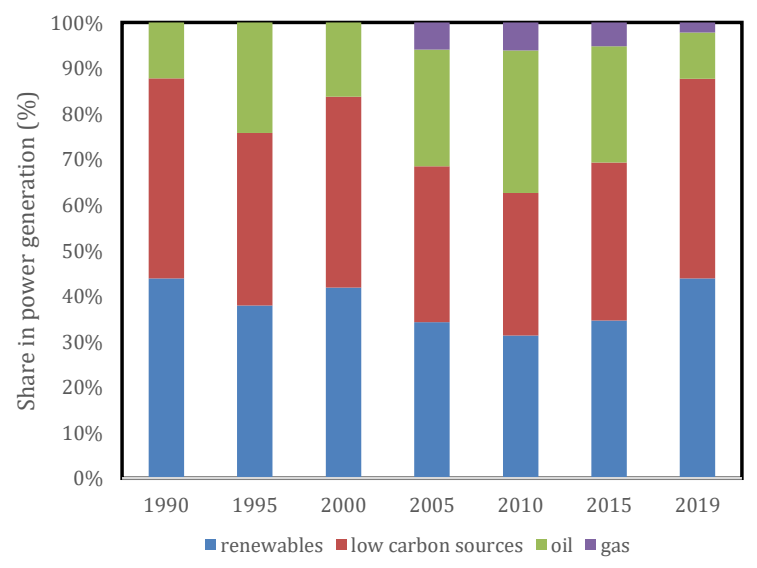

Figure 5. Evolution of power production by the carbon emission amount. Source: Author-made considering other drivers such as population and other economical sections is also very important.

Other policies used by the Ecuadorean government to implement energy transition principles are mentioned below [44]. The regulatory framework for electricity is the Electric Law of 2015, which explicitly states an objective of promoting renewable energy sources, including solid-waste biomass. This law establishes that the Ministry of Electricity and Renewable Energy (Ministerio de Electricidad y Energía Renovable MEER) is the governmental entity in charge of the regulation and planning of the entire power sector of the country, and hence carries the responsibility of promoting renewable energy. The law sets out preferential regulations for renewable energy, which are still under development by the newly created electricity agency (ARCONEL) and are expected to be issued in the second half of 2015. Previously, the Electric Law of 1996 mandated the now-disbanded National Electric Council (CONELEC) to promote renewable energy through special dispatch regulations [45].

From 2000-2015, Ecuador had a feed-in tariff system to support renewable electricity deployment. The feed-in tariff evolved in terms of duration, rates and technologies included. In 2013, Regulation CONELEC 001/13 removed solar PV from the feed-in tariff and set overall technology-specific capacity limits for wind, biomass and biogas, CSP, ocean energy, and geothermal installations eligible for the tariff. In 2014, Resolution CONELEC 014/14 maintained the feed-in tariff only for biomass and biogas, with differentiated rates for the first time, and hydropower smaller than 30MW [46].

Small-scale generators smaller than 1MW do not require a permit for operation (Decree 1581 of 1999). However, to benefit from the feed-in tariffs, they needed to be registered with the CONELEC. The procedures for registration of small projects were established in 2008 by

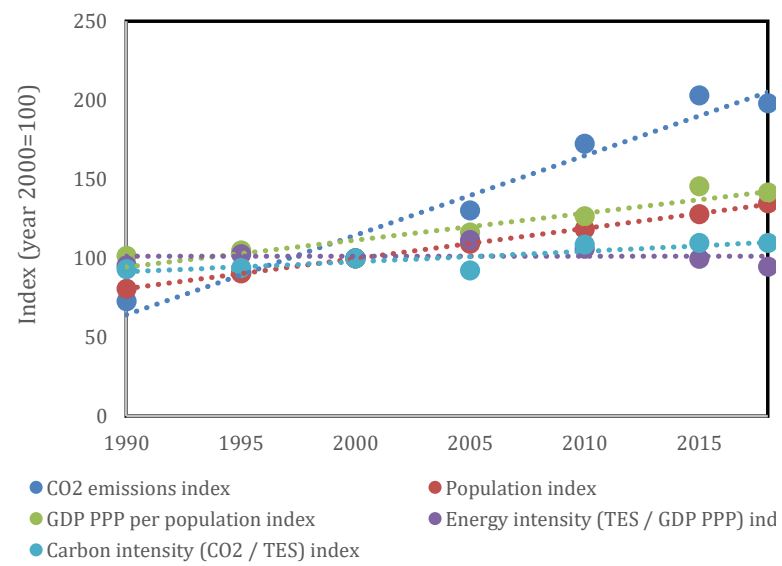

Figure 6. Evolution of carbon emission drivers. Source: Authormade. Source: Author-made 
Regulation CONELEC 009/08. In 2013, Regulation CONELEC 002/13 superseded the 2008 regulation and introduced two payments: a registration guarantee of 7,000 USD for projects smaller than $500 \mathrm{~kW}$ and 15,000 USD for projects larger than $500 \mathrm{~kW}$; and an execution guarantee of one percent of the total project cost [47].

Grid access was facilitated by the feed-in tariff regulations, which mandated preferential dispatch for renewables. In the 2004 and 2006 feed-in tariff regulations, preferential dispatch was mandated until renewable generation reached two percent of the total electric system generation capacity, at which point new renewable energy generators would dispatch on an economic merit basis. In 2008, Regulation CONELEC 013/08 established preferential dispatch for renewable electricity, up to a maximum of six percent of operative installed capacity [32]. In 2012, Resolution CONELEC 102/12 exempted hydro, biomass, and geothermal from the preferential dispatch limit.

When a project developer builds a transmission line to connect a renewable energy project to the grid, it can obtain compensations for its expenditure, the levels of which were established by the feed-in tariff regulations of 2002, 2004, and 2006 as an additional 0.06 cents $/ \mathrm{kWh} / \mathrm{Km}$, with a maximum cost of 1.5 cents $/ \mathrm{kWh} / \mathrm{Km}$ [36]. Since 2013 (Regulation CONELEC 001/13), connection to the grid requires the payment of a non-refundable fee (10.000 USD for projects larger than $1 \mathrm{MW}$ and 5000 USD for projects smaller than 1MW) to the transmission or distribution company for a connection feasibility study. Payment of the fee does not guarantee a connection. Once a project is cleared for connection, a guarantee of 0.5 percent of total investment is required, refundable when the project begins operation on the agreed timelines [48].

Fiscal incentives were provided by the Electric Law of 1996, which provided import duty exemptions for solar, wind, geothermal, and biomass equipment, as well as a five-year income tax exemption for renewable energy developers. The 2015 Electric Law does not contain similar fiscal provisions. Since 2011 (CONELEC 004/11) renewable energy projects receiving the feed-in tariff must contribute an amount (per $\mathrm{kWh}$ generated) to social and community development projects (Estado del Buen Vivir). As of 2014 (CONELEC 014/14), the amount is as shown in the below table [49].

Subsidies for electricity and fuel are major barriers to the promotion of energy efficiency programs and renewable energy use in the manufacturing, service, and residential sectors. Although subsidies and the total absorption of investments by the state may constitute a risk to the financial sustainability of long-term projects (due to the pressure exerted by these measures on the national economy), this risk can be mitigated with the appropriate security and investment protection measures. However, there may be other institutional barriers. There remains, for instance, the problem of coordinating efforts between various government and private institutions to reach all end-users of energy [26].

Renewable energy sources are expected to play a growing part in meeting future energy demands, and with the right government, support will ideally one day end Ecuador's dependence on imported fossil fuels [27].

Considering all these regulations implemented in the Ecuadorian energy sector to drive the energy transition, the results shown in Figure 7 illustrate the carbon intensity in the energy sector from 1990 to 2018, which shows a steady decreasing trend of the carbon emitted for a unit of energy produced. This trend shows the success of the energy transition policy in the Ecuadorian energy system.

\section{DISCUSSION}

In the last decade, in continental Ecuador, the wind and solar potential began to be exploited due to the need to diversify the energy matrix and increase the capacity of the system. Wind generation began to be implemented in 2012 with the construction of the Villonaco Wind Power Plant. This was the first large-scale wind project located in the province of Loja, in southern Ecuador [12, 22].

Since then, the National Institute of Energy Efficiency and Renewable Energies INER developed a macro methodology to determine the best location for wind plants in Ecuador, and it shows that the Andean region of Ecuador has significant potential for wind generation $[13,28]$.

In the first phase of 2015-2025, the transition begins with the application of energy efficiency measures and the implementation of energy technologies (thermo-solar, biomass, mini-wind, solar roofs). The construction of large renewable plants is characterized to compensate for the output of fossil plants. Learning processes and incen-

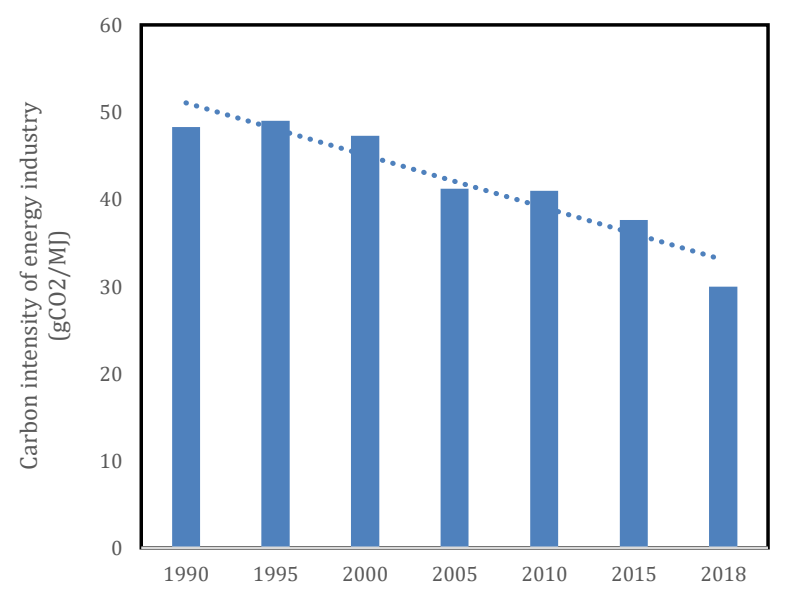

Figure 7. Ecuadorian energy transition to a greener energy sector. Source: Author-made 
-tives are carried out to increase the popularity and adoption of decentralized generation systems at the regional and urban levels [50]. By 2025, all new power plants are expected to be powered by renewable energy sources [24].

At the residential and commercial level, all devices and machines will be powered by electricity (heating, drying, and cooking of food). This is feasible because versions of all these products are already available and can be used without any adaptation. At the end of the period, global demand could be: $130.0 \mathrm{TWh} /$ year, and the demand for fossil fuels and natural gas would be 110 $\mathrm{TWh} /$ year $[23,51]$.

The second phase 2025-2035 is characterized by the massive implementation of decentralized renewable energy systems (solar roofs, mini-wind, virtual energy storage, and management systems, demand management, and electric vehicles). At the end of the period, global demand could be: 100.0 TWh/year, and the demand for fossil fuels and natural gas would be $20 \mathrm{TWh} /$ year [30, 52].

The expansion of renewable energies with variable sources requires considering technologies to ensure the stability of the network, so it is necessary to plan together with the expansion the implementation of storage systems that allow energy management and boost the energy autonomy of cities [28, 53].

In the field of transport, by 2035 all buses, trucks, and light cars will be electrified or will use electrolytic hydrogen. This will require changes in the energy supply infrastructure. However, if all transport vehicles can run on batteries (electric and/or hydrogen) this would simplify the conversion because the supply and recharge points would be everywhere in the form of electric stations, therefore this can take from 10 to 15 years for manufacturers to fully overhaul and for sufficient backup power supply infrastructure $[11,54]$.

The third phase 2035-2045 is the phase of consolidation of the actions undertaken, the new users are integrated into the system, the remaining mobility systems are converted to electric traction, and the pedagogy programs on energy efficiency and savings are maintained. At the end of the period, global demand could be: $85.0 \mathrm{TWh} /$ year, and the demand for fossil fuels and natural gas would be $4 \mathrm{TWh} /$ year $[11,55]$.

The fourth phase 2045 - 2055 shows the projection of energy demand by source, BAU scenario $(358,000$ $\mathrm{GWh})$, and the estimated target demand $(80,000 \mathrm{GWh})$ with a $100 \%$ renewable energy infrastructure (zero fossil fuels) $[23,56]$. In 2055, the management of a $100 \%$ renewable system begins and this must be supported by a system of measurement and data acquisition in real-time at the aggregate level (substation feeders) and disaggregated (at the user level). In addition to integrating the management of storage systems to optimize renewable generation [31].
During the transition, conventional fuels will be needed along with existing renewable technologies to produce the remaining renewable infrastructure. Furthermore, the use of such fuels results in the respective carbon emissions in the life cycle. The importance of energy efficiency, the integration of renewable energies to reduce the demand for fossil fuels, pedagogy in good uses of energy, and the conversion of transport and mobility to electric traction is highlighted.

\section{CONCLUSION}

This paper is after studying Ecuador as one of the premiers of the energy transition in the post-covid-19 world. The results of this paper show that Ecuador was mainly successful in implementing a " $100 \%$ renewable" policy which is supported by its new constitution (called the green constitution). But the total carbon emission shows that, despite decarbonization in the energy industry, the total amount of carbon emissions is rising due to economic and population growth. Thus this paper discusses that the $100 \%$ renewable policy cannot be enough to face the climate change issue and a deeper revision of the development theory and economic system is needed to be implemented.

\section{ACKNOWLEDGEMENT}

The authors are thankful to Amirkabir University of Technology for the scientific supports.

\section{REFERENCES}

1. Alves, M., Segurado, R. and Costa, M., 2020. On the road to $100 \%$ renewable energy systems in isolated islands. Energy, 198, pp.117321. Doi:10.1016/j.energy.2020.117321

2. Esteban, M., Portugal-Pereira, J., Mclellan, B.C., Bricker, J., Farzaneh, H., Djalilova, N., Ishihara, K.N., Takagi, H. and Roeber, V., 2018. 100\% renewable energy system in Japan: Smoothening and ancillary services. Applied energy, 224, pp.698-707. Doi:10.1016/j.apenergy.2018.04.067

3. Child, M., Bogdanov, D. and Breyer, C., 2018. The role of storage technologies for the transition to a $100 \%$ renewable energy system in Europe. Energy Procedia, 155, pp.44-60. Doi:10.1016/j.egypro.2018.11.067

4. Hansen, K., Mathiesen, B.V. and Skov, I.R., 2019. Full energy system transition towards $100 \%$ renewable energy in Germany in 2050. Renewable and Sustainable Energy Reviews, 102, pp.1-13. Doi:10.1016/j.rser.2018.11.038

5. Uyar, T.S. and Beşikci, D., 2017. Integration of hydrogen energy systems into renewable energy systems for better design of $100 \%$ renewable energy communities. International Journal of Hydrogen Energy, 42(4), pp.2453-2456. Doi: $10.3390 /$ en 13153883 
6. Müller-Kraenner, S., 2008. Energy security: re-measuring the world. Earthscan. Doi:10.3390/en13153883

7. Unnerstall, T., 2017. Conclusion from an International Perspective. In: The German Energy Transition. Springer, Berlin, Heidelberg. Doi:10.1007/978-3-662-54329-0_22

8. Pinto, N.N. ed., 2013. Technologies for Urban and Spatial Planning: Virtual Cities and Territories: Virtual Cities and Territories (Vol. 2326, No. 6139). IGI Global. Doi:10.1016/j.esd.2013.02.001

9. Sørensen, B., 2016. Energy, Resources and Welfare: Exploration of Social Frameworks for Sustainable Development. Academic Press. Doi:10.1109/ICRERA47325.2016.8997114

10. Sørensen, B. and Spazzafumo, G., 2018. Hydrogen and fuel cells: emerging technologies and applications. Academic Press. Doi:10.1016/j.renene.2018.03

11. Robalino-López, A., Mena-Nieto, A. and García-Ramos, J.E. 2014. System dynamics modelling for renewable energy and $\mathrm{CO}_{2}$ emissions: A case study of Ecuador. Energy for Sustainable Development, 20, pp.11-20. Doi:10.1016/j.esd.2014.02.001

12. Villacreses, G., Gaona, G., Martínez-Gómez, J. and Jijón, D.J., 2017. Wind farms suitability location using geographical information system (GIS), based on multi-criteria decision making (MCDM) methods: The case of continental Ecuador. Renewable energy, 109, pp. 275-286. Doi:10.1016/j.renene.2017.03

13. Norouzi, N., Fani, M. 2021. The seventh line: a scenario planning strategic framework for Iranian $7^{\text {th }}$ energy progress plan by 2020 2025, Journal of Energy Management and Technology, 5(3), pp. 43-53. Doi:10.22109/jemt.2020.234795.1243

14. Norouzi, N., Fani, M. 2021. The prioritization and feasibility study over renewable technologies using fuzzy logic: A case study for Takestan plains, Journal of Energy Management and Technology, 5(2), pp.12-22. Doi:10.22109/jemt.2020.219626.1230

15. Icaza, D., Borge-Diez, D. and Galindo, S.P., 2021. Proposal of $100 \%$ renewable energy production for the City of CuencaEcuador by 2050. Renewable Energy, 170, pp.1324-1341. Doi:10.1016/j.renene.2021.02.067

16. Cevallos-Sierra, J. and Ramos-Martin, J., 2018. Spatial assessment of the potential of renewable energy: The case of Ecuador. Renewable and Sustainable Energy Reviews, 81, pp.1154-1165. Doi:10.1016/j.rser.2017.08.015

17. Hidrovo, A.B., Uche, J. and Martínez-Gracia, A., 2017. Accounting for GHG net reservoir emissions of hydropower in Ecuador. Renewable Energy, 112, pp.209-221. Doi:10.1016/j.renene.2017.05.047

18. Peláez-Samaniego, M.R., Garcia-Perez, M., Cortez, L.A.B., Oscullo, J. and Olmedo, G., 2007. Energy sector in Ecuador: Current status. Energy Policy, 35(8), pp.4177-4189. Doi:10.1016/j.enpol.2007.02.025

19. Icaza, D. and Borge-Diez, D., 2019, November. Potential Sources of Renewable Energy for the Energy Supply in the City of CuencaEcuador with Towards a Smart Grid. In $20198^{\text {th }}$ International Conference on Renewable Energy Research and Applications (ICRERA), pp. 603-610. Doi:10.1109/ICRERA47325.2019.8997114

20. Chilán, J.C.H., Torresb, S.G.P., Machucac, B.I.F., Cordova, A.J.T., Pérez, C.A.M. and Gámez, M.R., 2018. Social impact of renewable energy sources in the province of Loja: Ecuador. International journal of physical sciences and engineering, 2(1), pp.13-25. Doi:10.1016/j.renene.2018.03

21. Villacreses, G., Gaona, G., Martínez-Gómez, J. and Jijón, D.J., 2017. Wind farms suitability location using geographical information system (GIS), based on multi-criteria decision making
(MCDM) methods: The case of continental Ecuador. Renewable energy, 109, pp.275-286. Doi:10.1016/j.renene.2017.03.041

22. González, J.E., Coronel Espinoza, B., Quevedo Tumailli, V., Uvidia Cabadiana, H., Oliva, D., Morón, C.J. and Robles Campo, M., 2021. Biomass Potential and Kinetics of Drying Model of Piptocoma discolor (pigüe) as a Source of Renewable Energy Source in Ecuador. Enfoque UTE, 12(1), pp.74-90. Doi:10.29019/enfoqueute.695

23. Barzola, J., Espinoza, M. and Cabrera, F., 2016. Analysis of hybrid solar/wind/diesel renewable energy system for off-grid rural electrification. International Journal of Renewable Energy Research, 6(3), pp.1146-1152. Doi:10.1016/j.esd.2016.02.001

24. Arroyo M, F.R. and Miguel, L.J., 2020. The Role of Renewable Energies for the Sustainable Energy Governance and Environmental Policies for the Mitigation of Climate Change in Ecuador. Energies, 13(15), pp.3883. Doi:10.3390/en13153883

25. Arévalo, P., Cano, A. and Jurado, F., 2020. Comparative study of two new energy control systems based on PEMFC for a hybrid tramway in Ecuador. International Journal of Hydrogen Energy, 45(46), pp. 25357-25377. Doi:10.1016/j.ijhydene.2020.06.212

26. Barzola-Monteses, J. and Espinoza-Andaluz, M., 2019. Performance Analysis of Hybrid Solar/ $\mathrm{H}_{2} /$ Battery Renewable Energy System for Residential Electrification. Energy Procedia, 158, pp.9-14. Doi:10.1016/j.egypro.2019.01.024

27. Martínez, J., Martí-Herrero, J., Villacís, S., Riofrio, A.J. and Vaca, D., 2017. Analysis of energy, $\mathrm{CO}_{2}$ emissions and economy of the technological migration for clean cooking in Ecuador. Energy Policy, 107, pp.182-187. Doi:10.1016/j.enpol.2017.04.033

28. Nova, F.M., Icaza, D., Lojano, A., Herrera, L.C., Herrera, M.C. and Flores, C., 2019, November. Projection of a Renewable Energy System for the Observatory of Extraterrestrial Life in Ecuador and Peru. In $20198^{\text {th }}$ International Conference on Renewable Energy Research and Applications (ICRERA), pp.815-820. Doi:10.1109/ICRERA47325.2019.8996797

29. Soria, R., Caiza, G., Cartuche, N., López-Villada, J. and Ordoñez, F., 2020, Market potential of linear Fresnel collectors for solar heat industrial process in Latin-America-a case study in Ecuador, AIP Conference Proceedings 2303, pp.120003. Doi: $10.1063 / 5.0028503$

30. Albarracin, G., 2017. Urban form and ecological footprint: Urban form and ecological footprint: A morphological analysis for harnessing solar energy in the suburbs of Cuenca, Ecuador. Energy Procedia, 115, pp.332-343. Doi:10.1016/j.egypro.2017.05.030

31. Barbosa, L.D.S.N.S., Bogdanov, D., Vainikka, P. and Breyer, C., 2017. Hydro, wind and solar power as a base for a $100 \%$ renewable energy supply for South and Central America. PloS one, 12(3), pp.e0173820. Doi:10.1371/journal.pone.0173820

32. Jacobs, D., Marzolf, N., Paredes, J.R., Rickerson, W., Flynn, H., Becker-Birck, C. and Solano-Peralta, M., 2013. Analysis of renewable energy incentives in the Latin America and Caribbean region: The feed-in tariff case. Energy Policy, 60, pp.601-610. Doi:10.1016/j.enpol.2012.09.024

33. Mite-León, M. and Barzola-Monteses, J., 2018. Statistical model for the forecast of hydropower production in Ecuador. International Journal of Renewable Energy Research, 10(2), pp.1130-1137. Doi:10.1016/j.renene.2018.03.041

34. Lund, H. and Mathiesen, B.V., 2009. Energy system analysis of $100 \%$ renewable energy systems - The case of Denmark in years 2030 and 2050. Energy, 34(5), pp.524-531. Doi:10.1016/j.energy.2008.04.003

35. Mathiesen, B.V., Lund, H. and Karlsson, K., 2011. $100 \%$ Renewable energy systems, climate mitigation and economic 
growth. Applied energy, 88(2), pp.488-501. Doi:10.1016/j.apenergy.2010.03.001

36. Connolly, D., Lund, H., Mathiesen, B.V. and Leahy, M., 2011. The first step towards a $100 \%$ renewable energy-system for Ireland. Applied Energy, 88(2), pp.502-507. Doi:10.1016/j.apenergy.2010.03.006

37. Hansen, K., Breyer, C. and Lund, H., 2019. Status and perspectives on $100 \%$ renewable energy systems. Energy, 175, pp.471-480. Doi:10.1016/j.energy.2019.03.092

38. Ćosić, B., Krajačić, G. and Duić, N., 2012. A 100\% renewable energy system in the year 2050: The case of Macedonia. Energy, 48(1), pp.80-87. Doi:10.1016/j.energy.2012.06.078

39. García-Olivares, A., Solé, J. and Osychenko, O., 2018. Transportation in a $100 \%$ renewable energy system. Energy Conversion and Management, 158, pp.266-285. Doi:10.1016/j.enconman.2017.12.053

40. Mathiesen, B.V., Lund, H., Connolly, D., Wenzel, H., Østergaard, P.A., Möller, B., Nielsen, S., Ridjan, I., Karnøe, P., Sperling, K. and Hvelplund, F.K., 2015. Smart Energy Systems for coherent 100\% renewable energy and transport solutions. Applied Energy, 145, pp.139-154. Doi:10.1016/j.apenergy.2015.01.075

41. Norouzi, N., 2021. Post-COVID-19 and globalization of oil and natural gas trade: Challenges, opportunities, lessons, regulations, and strategies. International Journal of Energy Research, 45(10), pp.14338-14356. Doi:10.1002/er.6762

42. Norouzi, N. and Ataei, E., 2021. Covid-19 Crisis and Environmental law: Opportunities and challenges. Hasanuddin Law Review, 7(1), pp.46-60. Doi:10.20956/halrev.v7i1.2772

43. Norouzi, N., Khanmohammadi, H.U. and Ataei, E., 2021. The Law in the Face of the COVID-19 Pandemic: Early Lessons from Uruguay. Hasanuddin Law Review, 7(2), pp.75-88. Doi:10.20956/halrev.v7i2.2827

44. Kroposki, B., Johnson, B., Zhang, Y., Gevorgian, V., Denholm, P., Hodge, B.M. and Hannegan, B., 2017. Achieving a 100\% renewable grid: Operating electric power systems with extremely high levels of variable renewable energy. IEEE Power and energy magazine, 15(2), pp.61-73. Doi:10.1109/MPE.2016.2637122

45. Norouzi, N., de Rubens, G.Z., Choupanpiesheh, S. and Enevoldsen, P., 2020. When pandemics impact economies and climate change: exploring the impacts of COVID-19 on oil and electricity demand in China. Energy Research \& Social Science, 68, pp.101654. Doi:10.1016/j.erss.2020.101654

46. Norouzi, N., Zarazua de Rubens, G.Z., Enevoldsen, P. and Behzadi Forough, A., 2021. The impact of COVID-19 on the electricity sector in Spain: An econometric approach based on prices. International Journal of Energy Research, 45(4), pp.63206332. Doi: $10.1002 /$ r. 6259

47. Norouzi, N. and Fani, M., 2020. The impacts of the novel corona virus on the oil and electricity demand in Iran and China. Journal of Energy Management and Technology, 4(4), pp.36-48. Doi:10.22109/jemt.2020.222593.1232

48. Norouzi, N. and Kalantari, G., 2020. The sun food-water-energy nexus governance model a case study for Iran. Water-Energy Nexus, 3, pp.72-80. Doi:10.1016/j.wen.2020.05.005

49. Lund, H., 2009. Renewable energy systems: the choice and modeling of $100 \%$ renewable solutions. Academic Press. Doi:10.1016/j.apenergy.2009.03.006

50. Connolly, D., Lund, H. and Mathiesen, B.V., 2016. Smart Energy Europe: The technical and economic impact of one potential 100\% renewable energy scenario for the European Union. Renewable and Sustainable Energy Reviews, 60, pp.1634-1653. Doi:10.1016/j.rser.2016.02.025

51. Norouzi, N. 2021. Assessment of Technological Path of Hydrogen Energy Industry Development: A Review, Iranian (Iranica) Journal of Energy \& Environment, 12(4), pp.1-12. Doi:10.5829/ijee.2021.12.04.01

52. Behzadi Forough, A., Norouzi, N., Fani, M. 2021. More Secure Iranian Energy System: A Markal Based Energy Security Model for Iranian Energy Demand-side. Iranian (Iranica) Journal of Energy \& Environment, 12(2), pp.100-108. Doi:10.5829/ijee.2021.12.02.01

53. Heshmat, S., Hashemi Monfared, S., Yousefi Kebria, D., Banihashemi, S., 2020. Identification of Characteristics Influencing Wave Height and Current Velocity in MIKE Model for Simulation of Wind-induced Ocean Currents and Waves in Southeast of Caspian Sea. Iranian (Iranica) Journal of Energy \& Environment, 11(4), pp.330-338. Doi:10.5829/ijee.2020.11.04.11

54. Nemati, A. 2020. Three-dimensional Numerical Study of the Performance of a Small Combined Savonius-Darrieus Vertical Wind Turbine, Iranian (Iranica) Journal of Energy \& Environment, 11(2), pp.163-169. Doi:10.5829/ijee.2020.11.02.11

55. Tamoor, M., Sagir, M., Abbas, G., Ans Zaka, M., ZakaUllah, P. Design, 2020. Construction and Production of Small Scale Energy Generation Plant using Indigenous Resources. Iranian (Iranica) Journal of Energy \& Environment, 11(4), pp.308-319. Doi:10.5829/ijee.2020.11.04.09

56. Belay Kassa, A. 2019. Current Status, Future Potential and Barriers for Renewable Energy Development in Ethiopia, Iranian (Iranica) Journal of Energy \& Environment, 10(4), pp.269-274. Doi:10.5829/ijee.2019.10.04.07 
Norouzi and Fani / Iranian (Iranica) Journal of Energy and Environment 13(1): 1-9, 2022

\title{
COPYRIGHTS
}

(C)2021 The author(s). This is an open access article distributed under the terms of the Creative Commons Attribution (CC BY 4.0), which permits unrestricted use, distribution, and reproduction in any medium, as long as the original authors and source are cited. No permission is required from the authors or the publishers.

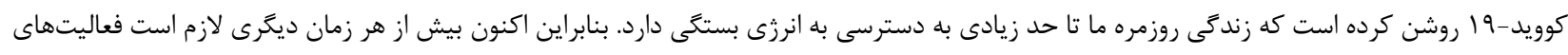

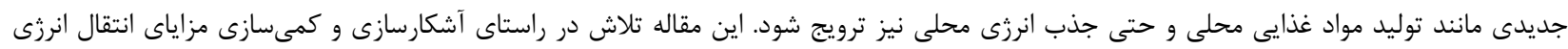

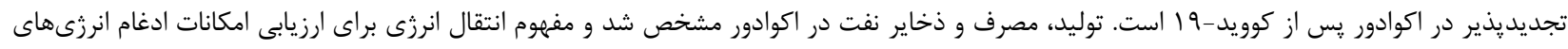

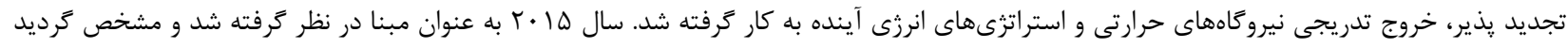

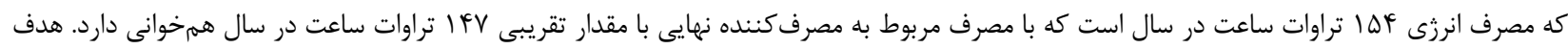

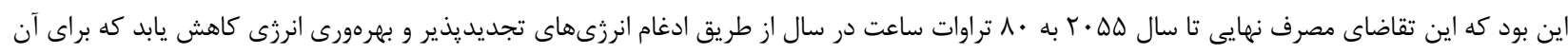

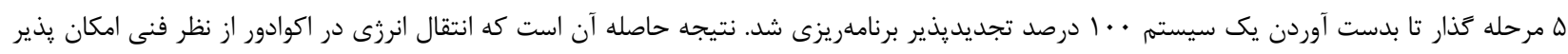

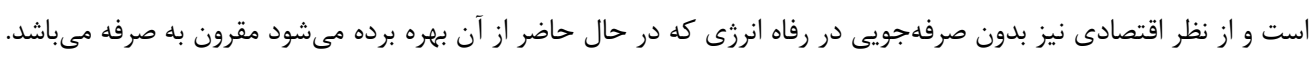

